\title{
Vienna and Budapest in American Secret Diaries in Early 1919
}

\author{
Zoltán Peterecz
}

Few historic periods have been more thoroughly studied and scrutinized than the Paris Peace Conference in 1919. The reason for this interest is hardly surprising since after the devastating First World War a truly new epoch started that was launched largely by the Peace Conference. Europe was made anew, old empires were gone and new states were born, while the new ideology of bolshevism arose to challenge the western democracies. Also, amid the general devastation brought on by the four long years of war, many states were financially and economically ruined and their resuscitation was only imaginable under previously unseen international cooperation. This last point was strengthened by the League of Nations called into being by the Peace Conference as well. Therefore, the minute study of the year 1919 in general, and the Conference in particular, is understandable.

This study is focusing on a special and small aspect of the turbulent first half of 1919. It examines and compares private diaries made during the half year stretching from December 1918 until May 1919. All three diaries in question were written by American officers, mainly during their stay in Vienna, Austria, and to a smaller degree in Budapest, Hungary, and Bucharest, Romania. All three authors came from similar background, were of similar age, and were members of the same American field mission, so their vantage point was also similar. In light of this, the article wants to compare the three diaries and highlight what similarities and perhaps differences can be found in them. Doing so, it will be seen what was the general line of thinking not only for these three men, but possibly for a much larger group of Americans: what they thought about post-war Europe, the role of the United States in this new Europe and the world at large, and, perhaps the most interesting factor, how they saw the possible implementation of the Wilsonian policy in the future.

It is imperative to introduce the three authors in a few words as to get a picture about who they were.

Walter Goodwin Davis (1885-1966) was born in Portland, Maine. He attended Exeter and later Yale in 1908. After completing his law studies at Harvard in 1911, he joined the firm of Shearman and Sterling in New York. Subsequently he pursued a business and banking career in his hometown, Portland. Following the American declaration of war against Germany in April 1917, Davis attended the Officers 
Training Camp at Plattsburg, New York, and received a commission as Captain of Infantry in early 1918. He was assigned to the Military Intelligence Service, and served as Assistant Military Attaché at Berne, Switzerland. After the November armistice he was attached to the American Commission to Negotiate Peace in Paris, subsequently being transferred to Vienna as a member of the Coolidge Mission, where he remained until March 1919. ${ }^{1}$

Charles M. Storey (1889-1980) came from a rather prominent New England family. His father, Moorfield Storey was a well-known lawyer in Boston, Massachusetts, with a long practice, various titles in associations, and was a liberal person in his political and legal outlook. ${ }^{2}$ His son, Charles Moorfield Storey, was a Harvard graduate, who, after getting his lawyer degree, worked in the Justice Department until the end of World War I. After the war he became a member of a law firm where he stayed for the remainder of his life. He held various posts as members, presidents, and trustees in different organizations, of which being Harvard overseer for five years made him the proudest. ${ }^{3} \mathrm{He}$ was a member of the Coolidge Mission.

Nicholas Roosevelt (1893-1982) was born in New York City among favorable circumstances. The Roosevelt dynasty was one of the most prominent and wealthiest families in the United States. Roosevelt belonged to the Long Island branch of the family, and lived close to Oyster Bay. His father, James Roosevelt, was the cousin of later President Theodore Roosevelt, who, after the premature death of James Roosevelt, mainly brought up Nicholas. During World War I he first worked as attaché at the American Embassy at Paris for sixteen months, then he was at Plattsburgh, New York, in a non-commissioned training camp. Later he was in Spain as a secretary to the American International Corporation, which errands provided him with invaluable insight into diplomacy and European affairs. At the time of the armistice he served in the rank of captain, and joined the Coolidge Mission as such in the last days of 1918.

The American Peace Delegation, exactly in order to learn about the often anomalous-looking Central European region, sent the Coolidge Mission to Vienna in the first day of 1919. This mission was responsible for gathering as much information as possible at its headquarters in Vienna and in the countries in the region: Hungary, Romania, the Kingdom of Serbs, Slovenes, and Croats,

1 The information was gleaned from Guide to the The Walter G. Davis Papers MS 469, compiled by N. X. Rizopolous with the assistance of Anne Willard, March 1973, New Haven, Connecticut.

2 Eugene Wambaugh, "Moorfield Storey (1845-1929)," Proceedings of the American Academy of Arts and Sciences, Vol. 71, No. 10 (Mar., 1937), 552-556.

3 Theodore Chase, "Charles Moorfield Storey," Proceedings of the Massachusetts Historical Society, Third Series, Vol. 92 (1980), 151-156. 
and Poland. The motley group of Coolidge's mission consisted of military officers, university and college professors, and lawyers. It was the mission's task to obtain valuable information concerning the present position and outlook of the countries mentioned and relay useful data to Paris to help the American Peace Delegation in making decisions. Archibald Coolidge sent the various members to the aforementioned countries and tried to keep the flow of information to Paris at a sustainable and satisfactory pace. ${ }^{4}$ The three individuals, Davis, Storey, and Roosevelt, were all members of this mission. All started their diary entries in Paris, which activity must have been spurred by the momentous circumstances of peace making after the devastating war.

What are really diaries and what is their significance from the point of view of studying history? Diaries are a personal mirror on history. Although reflected and retained through this personal lens, and therefore distortions are natural, history presented from the first person singular perspective enriches our knowledge about a certain event or period. The diary as a form of and mirror on history has been around for centuries, but the first detailed diary entries came into being during the Renaissance, which era produced an earlier unknown measure of self-consciousness and, in the wake of it, a larger need for self-reflection. ${ }^{5}$ The almost universal practice of putting down observations in a diary, however, really became in vogue in the mid-nineteenth century. Most typically, persons belonging to the upper classes in general grabbed their pens, but diplomats and politicians in particular were active in this field. Today, this form of preserving the present seems to be on the wane, largely due to the digital and globalized world, where the visual image is taking its place. The diary entry is a living imprint of history, since those persons scribbling down events into their diaries reflect fresh experience and observation, and they do it right after the event takes place, so the usually distorting feature of many years and distant memory do not play a role in being historically correct. On the other hand, the diary entry can also be seen as a form of literature, even if the notes sometimes in short form are not representatives of fine literature. That is why it has an "unsure status," because the diary is "an uncertain genre uneasily balanced between literary and historical writing, between spontaneity of reportage and the reflectiveness of the crafted text, between selfhood and events, between

4 For the history of the Coolidge Mission see Harold Jefferson Coolidge and Robert Howard Lord, Archibald Cary Coolidge: Life and Letters, (Boston and New York: Houghton Miffin, 1932), 192216.

5 David L. Ransel, "The Diary of a Merchant: Insights into Eighteenth-Century Plebeian Life," The Russian Review, Vol. 63, No. 4 (Oct., 2004), 596. 
subjectivity and objectivity, between the private and the public." ${ }^{6}$ Obviously, one always has to be on guard when faced with a diary entry, because, if nothing else, the unavoidable subjectivity will play a part.

Still, these entries usually reflect history well. This does not mean that we should look at diaries as refutable historical artifacts, since these texts are personal "images" only. ${ }^{7}$ Coloring, magnifying, and distorting facts, as well as errors are all characteristic of it, but that also holds true for professional history writing. Although there are naturally plenty counterexamples, in most cases the author of a diary entry does not purposefully distort the story he or she writes down. The author's primary goal is clearly to preserve the present and not to lie about history. ${ }^{8}$ The author wishes on reading the entries to be able to reproduce events and feelings ten, twenty, thirty, or more years later, irrespective of its nature-family, politics, or war. So, while a historian mainly analyzes the past, a diary entry mainly preserves it. This preservation may show signs of idiosyncrasies, also those of an analytical mind of the observer, but it presents history as it was for that individual.

Depending on time and place, the level of "freedom" of the diary entries may also differ. If someone lives in a society and jots down events when they do not need to worry about the material getting into the wrong hands, the opinion will be a more open one, the author will be committed to a more "honest" style. On the contrary, in the atmosphere of an oppressive regime, a diary person will choose circumventing wording and style, even perhaps a code, driven by the fear what might happen to them if the authorities find the entries, read them, and, as a consequence, punish the author and /or their family. Seen from this point of view, the authors of the three diaries examined here, it can be stated that they could write as freely as they wished, even if some of the entries were put down in "enemy countries" - they did not need to worry about being punished for their contents. Naturally, only looking back a hundred years later can we appreciate the historical significance of some of the entries in these diaries. ${ }^{9}$

All three of these Americans were then headquartered in Vienna, where they gathered information first and foremost by meeting and interviewing various shades of Austrians. They made shorter or longer trips to Hungary as well, and in

6 Rachael Langford and Russell West, eds., Marginal Voices, Marginal Forms: Diaries in European Literature and History (Amsterdam, 1999), 8.

7 Gábor Gyáni, „A napló mint társadalomtörténeti forrás”, [The Diary as Sociological Source] Szabolcs-szatmár-beregi levéltári évkönyv, 1997, vol. 12, 25.

8 Pál Pritz, „Napló és történelem”, [Diary and History] Múltunk, 2017, vol. 62, 1., 4-6.

9 This section on diaries as history is almost identical with Zoltán Peterecz, "Immediate Post-World War I Hungary through the Eyes of an American”, Hungarian Studies, vol. 32, no. 2, (2018), 306-7. https://doi.org/10.1556/044.2018.32.2.12 
the case of Storey and Roosevelt, also to Romania. If one studies the three diaries in some detail, there will be various points that stand out as the most conspicuous questions that interested all three persons. The most typical common features can be listed as the following: the possible danger of bolshevism, the role of the United States and of the Wilsonian principle in drawing up the new borders, Wilson as the self-proclaimed messiah of the new world order, dire circumstances in Vienna, political intrigue of the successor states, the impossible worldview of Hungarian nobles, daily chores of the mission (interviews with various people in Vienna and Budapest), daily life in Vienna and Budapest, Viennese opera, etc. It is worth looking at some of these points and see how closely the three intelligence officers thought about these points or whether there are major differences in their analysis of these issues. In the rest of the article, these issues will be introduced through the diary entries of the three Americans, and their notes will be compared as to prove whether they all saw the same things or whether there are discrepancies in how they experienced the surrounding events and personalities.

Clearly, one of the most defining issues in the immediate postwar worldview in the West in general, and in the United States in particular, was the fear of SovietRussian bolshevism and the panic that it might spread there from the East. The antagonism between the two nations went back a long time. In 1837, for example, a German-born American journalist described the eastern power in the following terms: "Russia is the evil genius of history; while America is its guardian angel. The power of Russia is opposed to the interests of humanity; that of the United States is based on wisdom and justice... The power of Russia rests on bayonets; that of America on the superiority of mind over brute force. They are to each other as darkness to light... The day of battle must come; the war of principles must ensue." 10 Toward the end of the nineteenth century another example is the following thesis: "At heart the Russian is still more Asiatic than European. We call him Christian; but his religion is a mingling of superstition and fanaticism less attractive, and certainly less conducive to morality, than the religion of the Bedouins." "So, when the Bolshevik revolution took place and started to show more and more antagonistic signs toward western and, especially, American thinking, not much was needed for a crusade-like atmosphere to gather that was an amalgam of righteousness and fear. As Hoover put it, after the war was over, "there began to loom up a greater fear from a more potent enemy of freedom than anarchy,

10 Francis J. Grund, The Americans, in Their Moral, Social, and Political Relations (Boston, 1837), 392393. Quoted in C. Vann Woodward, The Old World's New World, New York: Oxford University Press, 1991, 88.

11 William R. Thayer, "The Armed Truce of the Powers." Forum, vol. 12 (November 1891), 322. 
which after all is an unorganized force. Communism, which had captured Russia, was a new form of organized destruction of Liberty. And it was vengeance itself. The Communists had captured the Czarist gold reserves. Their agents spread over Europe, subsidizing a new revolution. Soon we began to realize that its infectious poison was spreading alarmingly among all starving peoples. Here loomed up a defeat of all we had fought for-to establish liberty." 12 To Robert Lansing, the American Secretary of State, bolshevism was "the most hideous and monstrous thing the human mind has ever conceived." 13 Many agreed with the conclusion of a US Senate subcommittee's paper that said: "The activities of the Bolsheviki constitute a complete repudiation of modern civilization." 14

As far as the members of the Coolidge mission are concerned, they could see some of the communistic leanings close up and personal. Therefore, it is interesting what they thought about it courtesy to their first-hand experience. Davis, when he spent two days in Budapest, a city where communist takeover had been expected by some, commented wryly on the situation as he saw it: "Today proved a disappointment. There was no Bolshevik revolution, no massacre of Christians." ${ }^{15}$ While Storey only hinted at the social problems that were connected with the possibility of a communist coup, Roosevelt, for his part, who was present when the Hungarian Soviet Republic was declared, was more vehement than his colleagues when it came to Bolshevism. In his mind, Bolshevism was a phenomenon spread by the Jews: "it is merely the work of a few unscrupulous Hungarian and Russian Jews, working with a few scoundrelly [sic] Austrian Jews, and playing on the feelings of a hungry mob to ride into power themselves." ${ }^{16}$ At the same time, he detected that there was a unifying force of the Bolshevik movement in Hungary on account of the drastic mutilation of the country's former territory.

When the subject of the diary entries was the role of the United States in the postwar world, the three men were in unison in their view. They all agreed that the various countries of war-torn Europe looked to the United States as the possible redeemer, whether the issue was economic, financial, or political in nature. Storey wrote that almost all of the European continent was "looking to America as a

12 Herbert Clark Hoover, The Memoirs of Herbert Hoover. Vol. 1-3. New York, The Macmillan Company, 1951-1952, vol. 1, 283.

13 Quoted in Michael H. Hunt, Ideology and U.S. Foreign Policy. New Haven and London, Yale University Press, 1987, 115.

14 Ibid.

15 Dairy entry, February 2, 1919, Walter G. Davis Diary, Box 1, Folder 16, Walter Goodwin Davis Papers (MS 469), Manuscripts and Archives, Yale University Library, USA.

16 Diary entry of April 21, 1919, A History of a Few Weeks, Box 18, Nicholas Roosevelt Papers, Syracuse University Libraries, United States, 423. 
composite savior, guardian angel, boundary commission, and food supply." ${ }^{17}$ In the defeated capitals of Central Europe, naturally, Americans were even more welcome. As Davis registered upon their arrival in Austria, "everyone to whom we have talked says emphatically that American officers are a welcome sight. They would be better pleased if we were accompanied by occupying troops." ${ }^{18}$ Roosevelt strengthened this view. "Everyone," he wrote, "no matter of what former persuasion or nationality, looks to America-Huns as well as Czechs; Slovaks as well as Slovenes; Austrians as well as Serbo-Croates; Roumanians as well as Ukrainians. America is apparently the referee in this big game, from their point of view." ${ }^{19}$ It is little surprise that both in Vienna and Budapest, the mission and its members were seen as the ultimate channel to the American Peace Delegation in Paris, as all three men's diaries attest.

Wilson's role was discussed in the diaries as well. The author of the Fourteen Points loomed large over everybody's mind in those months, and victors and defeated parties alike hoped the salvation from their own interpretation of Wilson's peace agenda. This was a major problem: different countries understood in different light what Wilson chose to say, obviously their interpretation favoring their own cause. The Fourteen Points were so universal and so idealistic that it was bound to create controversy and clearly could not satisfy all sides. The hub of it was national self-determination the lofty ideals of which it was impossible to live up to, and, consequently, it was unmanageable to do justice among the existing ethnic conditions in Central Europe. Secretary of State Robert Lansing was convinced "of the danger of putting such ideas into the minds of certain races. It is bound to be the basis of impossible demands on the Peace Congress and create trouble in many lands." ${ }^{20} \mathrm{He}$ found the phrase was "loaded with dynamite" that would only raise hopes in vain, and finally would be "discredited, to be called the dream of an idealist who failed to realize the danger until too late to check those who attempt to put the principle in force." ${ }^{21}$ While Storey only referred to the unfeasibility of the principle in Transylvania, where one purely Romanian village was followed by a similarly pure Hungarian settlement, he criticized Wilson for his veneer of idealism that tried to conceal hard truths. The president, he said, "comes to the Conference, unprepared, and undismayed-Sir Galahad from the West with a wooden sword

17 Diary entry, November 26, 1918, Charles Moorfield Storey Journal, 1918-1919, Massachusetts Historical Society, United States.

18 Diary entry, January 5, 1919, Davis Diary.

19 Diary entry, April 21, 1919, A History of a Few Weeks, 152.

20 Diary entry, December 30, 1918, In. Robert Lansing, The Peace Negotiations: A Personal Narrative (New York: Houghton Mifflin, 1921, 97.

21 Ibid., 97-98. 
to carve the casques of some of the hardest-headed individuals in Europe today."22 But Roosevelt was once more sharper when it came to condemning Wilson. He accused the president with undue and exorbitant optimism, and characterized the president as someone who opted for "a well-worded, moralistic rhetorical sentence" instead of practical foreign policy. For Roosevelt such rhetoric would, and he mainly had Wilson's Fourteen Points in mind, give the false impression that "this verbal patent medicine will purge Europe of her ills overnight, and introduce the reign of brotherly love." 23

Perhaps it is of interest to compare the opinions on Hungarians in general, or on some specific persons. Although one cannot find exactly corresponding subjects of deep analysis in the diaries of the three Americans, more than one outstanding person was written about in detail. For obvious reasons, Mihály Károlyi, President of Hungary at that time, was one such person. Storey was struck by the Hungarian leader "as being sincere, honest, a man prone to think better of the world that it deserved, an idealist... an extremely human person, capable of exciting a blind affection, based as much on his weakness as on his strength." ${ }^{24} \mathrm{He}$ added that, in his view, Károlyi was "an idealist, something of a dreamer, scrupulously honest, considered by some a poor judge of men and subject to the influence of stronger characters. Personally he is extremely attractive, a good talker and has made on all of us a deep impression. There is no doubt as to the depth and sincerity of his conviction and to his force. To my mind he is an extremely forceful personality, and has displayed considerable political instinct." ${ }^{25}$ As for Roosevelt, he also met and held conversations with Károlyi. His basic impression was also praise and a mild enchantment. He characterized Károlyi as "a sincere patriot," who "through his patriotism [...] took the helm, only to be faced by impossible problems, attacked from within and without, with nowhere to turn." 26 This last point soon materialized when the so-called Vix Note was handed over to Károlyi, and where N. Roosevelt was also present. ${ }^{27}$ The Vix Note was to inform the

22 Dairy entry, December 14, 1918, Storey Journal.

23 Diary entry without date, but it is from late March, 1919, Nicholas Roosevelt, A History of a Few Weeks, 383.

24 Dairy entry, January 15, 1919, C. M. Storey Journal.

25 Storey to Dulles, February 3, 1919, Storey, Charles M. 1919, Box 53 Folder 19, Allen W. Dulles Papers; Public Policy Papers, Department of Rare Books and Special Collections, Princeton University Library.

26 Diary entry of March 20, 1919, A History of a Few Weeks, 279.

27 Fernand Vix (1876-1941), French military officer, the leader of the Inter-Allied Military Mission in Budapest in 1919. He handed over the allied note to president Mihály Károlyi on March 20, 1919, which the latter and his government could not accept and resigned instead, opening the way for a communist takeover. 
Hungarian government to withdraw deep into its former territory, and it basically foreshadowed the dismemberment of Hungary at the Peace Conference.

Albert Apponyi was the grand old man of Hungarian politics, the most wellknown figure outside Hungary. While Storey remembered more vividly Apponyi's looks and his command of the English language, Roosevelt formulated a deeper opinion about the Hungarian. The two had actually met fifteen years earlier, when Apponyi visited Theodore Roosevelt at Oyster Bay. The Apponyi of present day basically gave a presentation of how Hungary would seek revenge if it were mutilated with millions of Hungarians left outside the mother country. Even worse, he implied that in the case of dismemberment, the Hungarians living in the United States, together with the Germans there, would make a united effort against Wilson and the Democratic Party. Roosevelt was, of course, a Republican but such a brazen threat against American democracy left him angry. No wonder that his assessment of Apponyi was mixed at best: "He is an interesting old scoundrelvery intelligent, perfectly unrepentant, and a thorough Chauvinist." 28

When it came to Pál Teleki, Storey again was struck by the extent to which an educated Hungarian noble could use English. Roosevelt, who met Teleki on more occasions, gave again a more thorough description of the man. Teleki had a very good impression on the American, partly because the latter learned a lot of information from the renowned geographer and cartographer, and future prime minister of Hungary. Teleki came through as "the most intelligent and in his line the ablest" among all the Hungarians Roosevelt had met. ${ }^{29}$ As Roosevelt noted, Teleki "gave me a mass of information that filled up many gaps in my scant knowledge of Hungarian affairs... I got almost everything I wanted to know." ${ }^{0}$ Naturally, Teleki was feeding the American with careful propaganda regarding the expected large ethnic Hungarian blocs in the successor countries, which is a further indication how everybody in these countries grasped any American as a possible channel to the highest decision makers at Paris.

Davis, for his part, wrote his impression concerning Hungarian nobles based upon his contact with them at Vienna. His opinion was not flattering. "These Hungarian aristocrats are absolutely impossible to converse with," he wrote in his diary, "their ideas are hopelessly sixteenth century, and with every breath they prove against themselves those accusations of feudal mentality made by Mr. SetonWatson. Countess Hadik told me as a proof of the uselessness of all Slovaques [sic], that the peasants on her husband's estates would never have learned even to speak

28 Diary entry of February 28, 1919, A History of a Few Weeks, 202.

29 Diary entry of April 16, 1919, A History of a Few Weeks, 279.

30 Diary entry of February 28, 1919, A History of a Few Weeks, 203. 
Magyar if he had not built schools and compelled them to go to them! A frank admission of the forcible magyarization of this nationality which is willing to suffer martyrdom rather than give up its own language." ${ }^{11}$ Storey gave a quick study of the other end of the spectrum-the Transylvanian Hungarians. The Szekler people struck him as crude but honest folks: "I must say that the Szeklers made us feel very much at home. To my mind they resembled our New Englanders, with a certain simplicity, sturdiness, and an independence amounting to obstinacy in many cases." 32 But from a political aspect the verdict was different, especially after conducting a handful of interviews in Kolozsvár: "In the first place all these people were so irreconcilable, so pigheaded, so narrow. In the second place they were utterly out of joint with the new tunes; and were being buoyed up with hopes for the return of the old royal order. Lastly they were not thinking; which were the saddest of all. The most that could be said was that they were brooding over present wrongs, and idealizing a dull and long moribund past." ${ }^{33}$

\section{Conclusion}

What is to be learned from these personal diaries written during the same time and place, based upon a very similar experience? These diaries do not contradict our knowledge of the events taking place in the aftermath of World War I in Central Europe. The facts are not challenged by these witness testimonies. What the entries reveal are mainly twofold. On the one hand, they allow the present-day reader a glimpse into what it was like to be a member of an American intelligence-gathering mission in early 1919 in Vienna and Budapest. The three authors' views basically corroborate each other as far as the daily challenges and tasks are concerned for the Coolidge Mission. On the other hand, and perhaps this is the real value of these pages written a little bit over a hundred years ago, the diaries introduce persons of historic fame and represent them as these American officers saw them. Their own personal slant was magnified beyond the pure facts. Largely unbiased opinions greet us when we read these diaries - inescapably peppered with individual preferences. The three diaries personalize two struggling Central European capitals, and also nations, that try to find the way out of the murky aftermath of a defeated war. Davis', Storey's, and Roosevelt's diaries enrich our collective knowledge of the early months of 1919, and tell us a lot about how the American officers of the day typically saw and related to their Central European host countries and the people living here.

31 Diary entry, February 13, 1919, Davis Diary.

32 Dairy entry, February 15, 1919, C. M. Storey Journal.

33 Dairy entry, February 19, 1919, C. M. Storey Journal. 